\title{
Seasonal Abundance of Phytoplankton in Relation to Physico- Chemical features of Venkammacheruvu Veeraghattam, Sriakulam(Dist.)A.P, India.
}

\author{
D.S.MadhavaRao ${ }^{1}$ and G.M.Narasimha Rao ${ }^{2}$ \\ ${ }^{2}$ Department of Botany, Andhra University, Visakhapatnam- \\ ${ }^{l}$ Department of Botany, Dr. VSK Government Degree College,(Autonamus) Visakhapatanam, A.P.
}

\begin{abstract}
Physico-chemical parameters of Venkammacheruvu in Veeraghattam, Andhra Pradesh, have been studied to understand the phytoplankton composition for twelve months (May 2014 to April 2015). A total of 75 genera belongs to four major groups such as chlorophyceae (32) Bacillariophyceae (16) Cyanophyceae (23) and Euglenophyceae (4) were reported. The phytoplanktonic concentration decreased during monsoon season, but increased rapidly with decline in water current and turbidity during post-monsoon months. The lower values for the plankton communities during monsoon season may be attributed to high inflow of water from the catchment area changing the hydrology of the system as a result of dilution. Hydrological and chemical parameters such as temperature, $p H, E C, D O, B O D$, total alkalinity, total hardness, calcium and magnesium hardness, chloride, phosphate, sulphate, nitrate and plankton composition were studied. Atmospheric temperature, water temperature, turbidity, nitrates, phosphates and magnesium of the study area has been shown to influence the phytoplankton composition in the lake studied.
\end{abstract}

Keywords: Phytoplankton, Physicochemical parameters, Venkammacheruvu, Srikakulam (Dist).

\section{Introduction}

Phytoplankton are possibly the most important group of organisms on earth generating most of the oxygen and also produce vegetative matter required at various links in a food chain( Jyoti et al.,2015). Phytoplankton form good indicators of water quality as they have rapid turn-over time and are sensitive indicators of environmental stresses (Agale et al.,2013). Phytoplankton communities are affected by physical, chemical and biological factors, making them valuable tool in monitoring programmes. Phytoplankton survey thus help to find out the trophic status and the organic pollution in the ecosystem (Ramchandra and Solanki 2007). On the basis of this, many workers have emphasized that algal communities as a whole serve as reliable indicators of pollution (Palmer, 1969; Nandan and Patel, 1986). Over the last few decades, there has been much interest in the processes influencing the diversity, distribution and development of phytoplankton communities (Bhosale, et al., 2010; Negi and Rajput, 2011) and in relation to physico-chemical factors (Jyothi and Narasimha rao. 2013; Achary, et al., 2010). Study of physico-chemical parameters is basic tool that contributes in making up of the ecosystems and determine the tropic dynamics of the water body.

Therefore in the present study investigations were conducted on fresh water phytoplankton along with physicochemical parameter. Seasonal diversity of phytoplankton in venkammacheruvu was studied to understand the distribution and diversity of microalgae in relation to environmental parameters from May 2014 to April 2015.

Study area:

The study region is situated at Venkampeta village, Veeraghattam mandal, Srikakulam District in NorthCoastal Andhra Pradesh. The study area locted in between $18.68^{\circ} \mathrm{N}$ latitudes $83.60^{\circ} \mathrm{E}$ Longitudes and elevation of $272 \mathrm{ft}$ from sea level. The agricultural lake occupies nearly 50 acres and receives water from rain and canal of Nagavali river. 

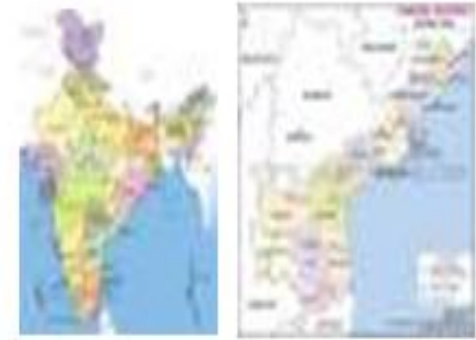

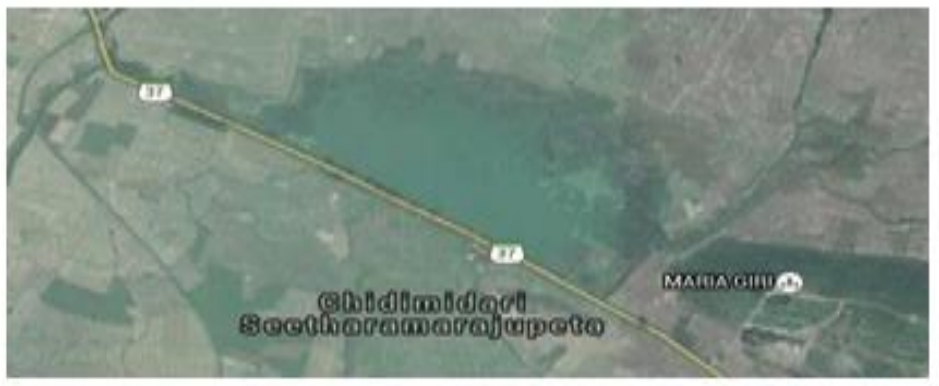

II. Matrerials and Methods

Physico-chemical Parameters were studied for one year From April 2014 to 2015. During the study period, the surface water samples were collected in clean plastic cans between 8 am to 10 am once a month. Water temperature was recorded on the spot. The samples for dissolved oxygen were fixed immediately on the field itself. The remaining parameters were analyzed as per the standard methods. Phytoplankton samples Turbidity, Temperature, $\mathrm{pH}$, Conductivity and Sacchi depth were measured with the help of Nephelometer, Thermometer, pH meter ,Conductometer and Sacchi disc. D.O and B.O.D. were determined by the modified Winkler's method. Water samples were also analyzed for Total alkalinity, dissolved solids, Suspended solids, Hardness, carbonate, bicarbonate, Calcium, Magnesium, chloride, Sulphates, silicate, nitrate, nitrates and phosphates (APHA, 2012).

\section{Phytoplankton analysis:}

Phytoplankton net (mesh size $25 \mu \mathrm{m}$ ) was swept on surface water and plankton was collected from Four stations and transferred into plastic containers and fixed in $4 \%$ formalin at spot. Then plankton samples were brought to the laboratory and centrifuged at 1500-2000rpm for 10-12 minutes..Phytoplankton were diluted to a desirable concentration in such a way that they could be easily counted individually under compound binocular microscope 10x and 40x and phytoplankton were measured and multiplied with the dilution factor, using Sedgwik rafter cell APHA as was described by Welch(1948) Smith(1950) Trivedi and Goel(1986) Kodarkar et.al(1991) and Dhanapati(2000). Phytoplankton were identified using standard monographs and manuals (Fritsch, 1907; Desikachary,1959; Chapmann,1962 ; Edmondson, 1963; Philipose, 1976; Prescott, 1984; Anand, 1998; ; .The "surface samples" are collected as close to the water surface as possible. Water samples were collected from 4 stations from May 2014- April 2015 in-between $8 \mathrm{am}$ to $10 \mathrm{am}$ and values of one year were taken for study. The collected samples were stored in pre-cleaned two litre plastic bottles, and brought to the laboratory with precautions for further chemical analysis.

\section{Qualitative and quantitative evaluation of plankton:}

The phytoplankton sample placed into the Sedgwick Rafter Counting chamber is allowed to stand on a flat surface for 20 minutes to enable the phytoplankton to settle. It is then transferred to the stage of an upright light microscope and securely positioned and counted (Laskar and Gupta, 2009). The abundance of phytoplankton groups was calculated according to the following formulae (Welch, 1948).

$$
\mathrm{N}=(\mathrm{A} \times 100) \mathrm{C} / \mathrm{L}
$$

Where $\mathrm{N}=$ Number of phytoplankton per liter of original water $\quad \mathrm{C}=$ Volume of original concentrate in $\mathrm{ml}$ $\mathrm{A}=$ Average number of phytoplankton in all counts in the counting cells $\mathrm{L}=$ Volume of water passed through the net

\section{Results and discussion}

Information on physicochemical parameters of the study area during April 2014 to May 2015 are presented in Fig.1. Minimum water and air temperatures $\left(18^{0} \mathrm{C}, 23^{0} \mathrm{C}\right)$ were reported in the month of February respectively. Higher temperatures of water and air $\left(35^{\circ} \mathrm{C}-29^{\circ} \mathrm{C}\right)$ were recorded in the month of May,2014 (Fig. 1A).Higher TDS value was observed in the month of May $(298 \mathrm{mg} / \mathrm{lit}$.) while minimum values were observed in December month (190mg/lit.). (Fig.1B). Higher Electrical Conductivity values were observed in April month $(424 \mu \mathrm{s} / \mathrm{cm})$, lower value was recorded in the month of August $(250 \mu \mathrm{s} / \mathrm{cm})$ (Fig.1B). Transparency was more in the month of November $(62 \mathrm{~cm})$, minimum transparency was observed in the month of July $(23 \mathrm{~cm})$ (Fig. 1C). TSS of the study area varied seasonally with higher value in July $(68 \mathrm{mg} / \mathrm{lit}$.) and lower value in December, January and April (10mg/lit.) (Fig. 1C). Turbidity of the study period higher value in July(14 NTU) due to rain water enters in the study area across the field and lower values in the months of October, November and December due to settle down the suspended particles (6NTU).(Fig. 1D).The $\mathrm{P}^{\mathrm{H}}$ values of the tank showed alkaline tends with a few variations the maximum $\mathrm{P}^{\mathrm{H}}$ values 8.4 in the month of May and minimum October 
and November (7.2) (Fig.2A). Higher Dissolved Oxygen values were observed in the months of November and December $(7.8 \mathrm{mg} / \mathrm{lit})$ (due to more photosynthetic activity of phytoplankton and lower value was observed in May(6.2 mg/lit.) due to high temperatures.(Fig.2 A) The total alkalinity observed more in the month of March (170mg/lit) and minimum value observed in September (80mg/lit) (Fig.2 B).The total hardness of the study area varied seasonally with higher value in March $(210 \mathrm{mg} / \mathrm{lit}$.) and lower value in May (90mg/lit) (Fig. 2B). Higher Carbonate value observed in the study area in the month of January $(30 \mathrm{mg} / \mathrm{lit})$ and lower value observed in the month of May(0 mg/lit).(Fig. 2C).Magnesium of the study area seasonally varied with higher value in the month of May (20mg/lit.) and lower observed in the month of November (7mg/lit.) (Fig. 2C). Sulphates were more in the month of September $(19 \mathrm{mg} / \mathrm{lit})$ of the study area and minimum were observed in June $(9 \mathrm{mg} / \mathrm{lit}$.) (Fig. 2C). Bicarbonates of the study area were maximum in the month of March (102mg/lit.) and the minimum values were observed in the month of September (48mg/lit.) (fig.2D). calcium was high in the month of January (48mg/lit.) of the study area and lower in the month of July $(16 \mathrm{mg} / \mathrm{lit}$.) was noticed.(Fig. 2D). Chloride is widely distributed in nature with calcium, potassium and sodium. The maximum chloride value in March (86mg/lit.) and minimum value was observed in the month of August (31mg/lit.) (Fig.2D). Biochemical Oxygen Demand (BOD) of the study area varied seasonally high value in the month of July (2.8mg/lit.) and lowest value was recorded in November (1.2mg/lit.) (Fig. 2E). The basic nutrient Nitrate value of the study area was high in the month of October $(0.82 \mathrm{mg} / \mathrm{lit}$.) and low value was recorded in the month of January $(0.21 \mathrm{mg} / \mathrm{lit}$.) (Fig. 2F). Phasphate of the study area was observed maximum in the month of August $(0.85 \mathrm{mg} / \mathrm{lit})$ and minimum value was in the month of December $(0.29 \mathrm{mg} / \mathrm{lit}$.) (Fig. 2F). Silicate was observed in the study area maximum in the month of October $(0.32 \mathrm{mg} / \mathrm{lit}$.) and minimum in the month of April $(0.05 \mathrm{mg} / \mathrm{lit}$.) (Fig. $2 \mathrm{~F})$.

Fig: 1. Physicochemical parameters of Venkamma Cheruvu during April 2014 to Ma y 2015
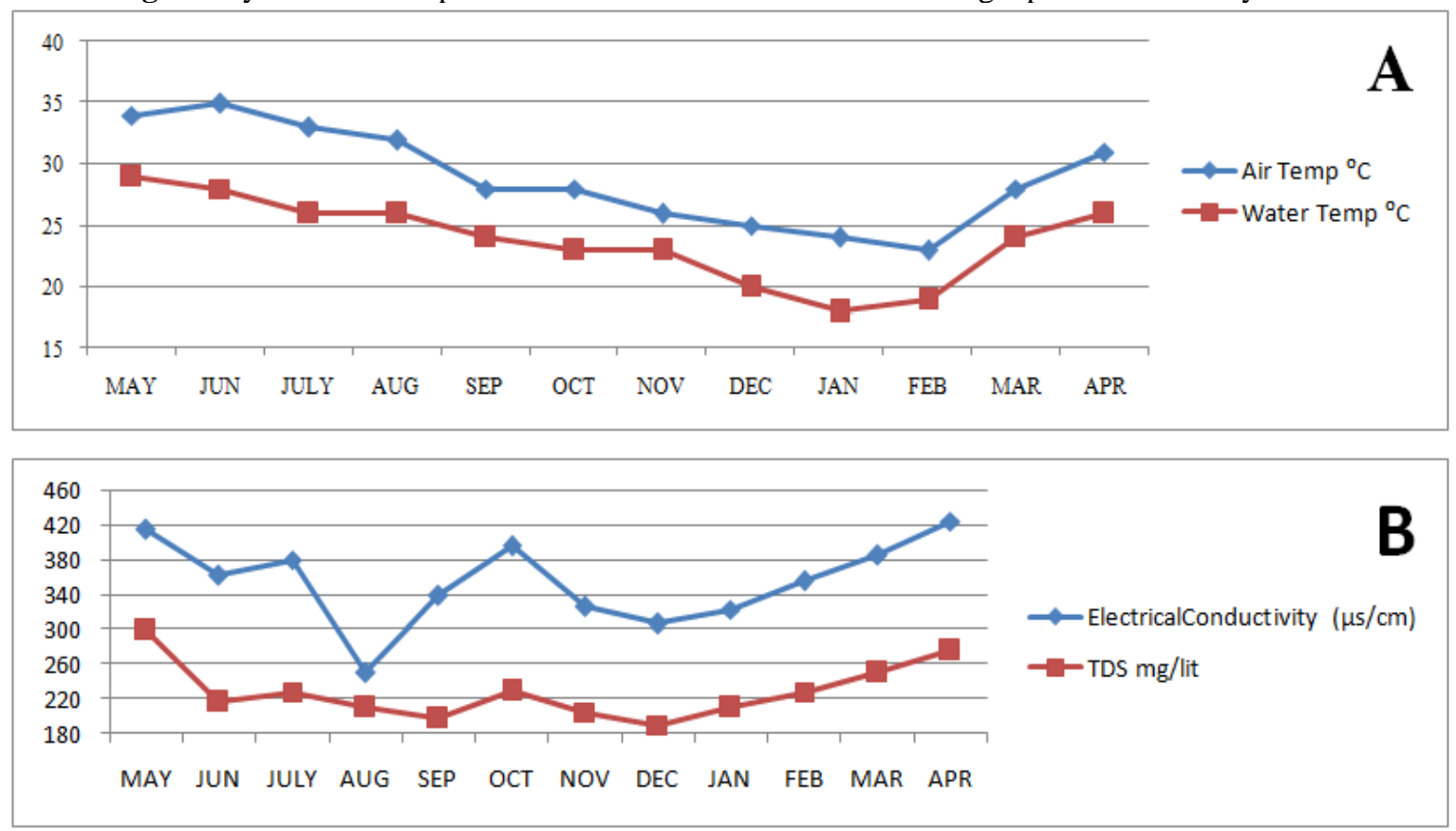

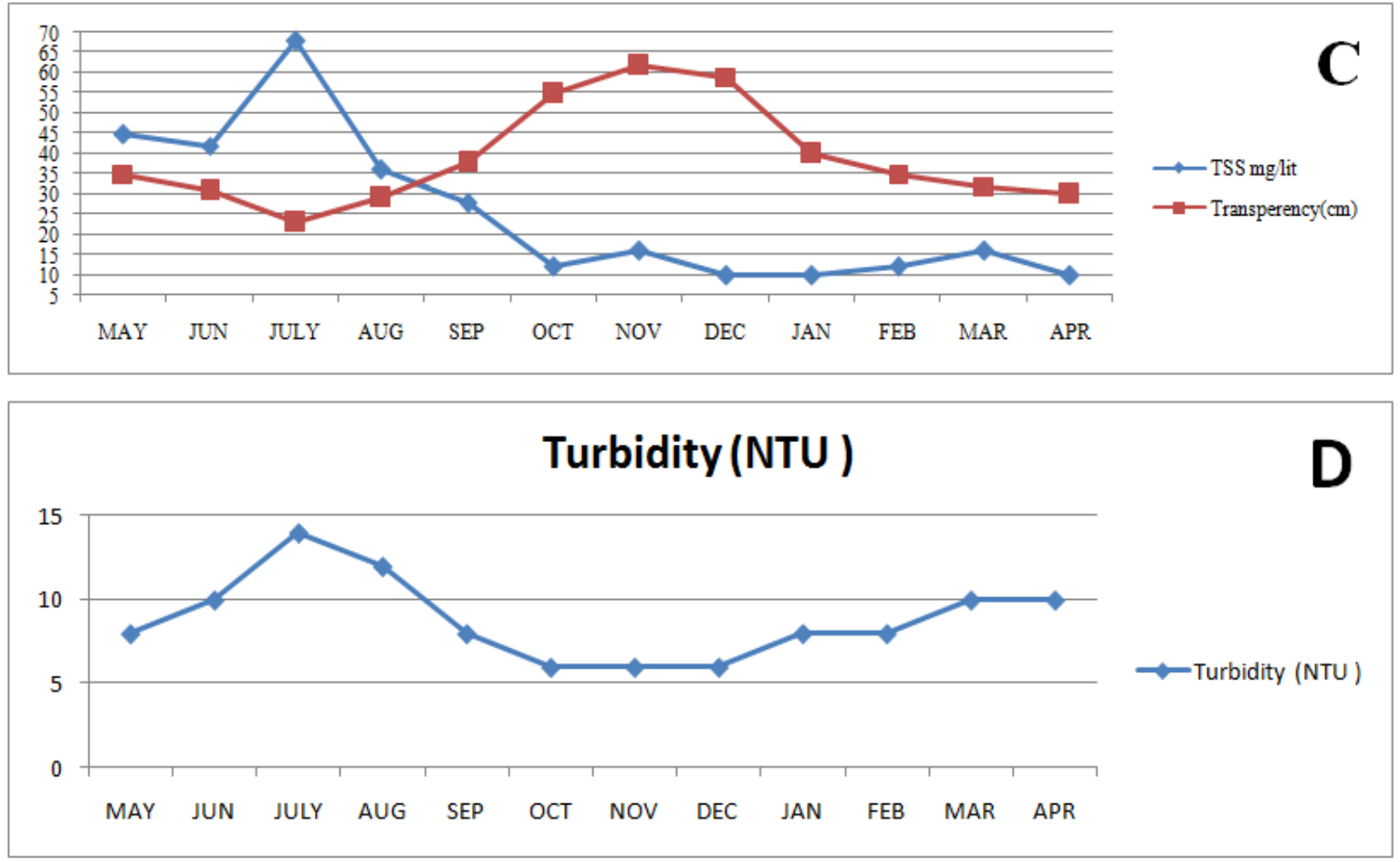

Fig.2
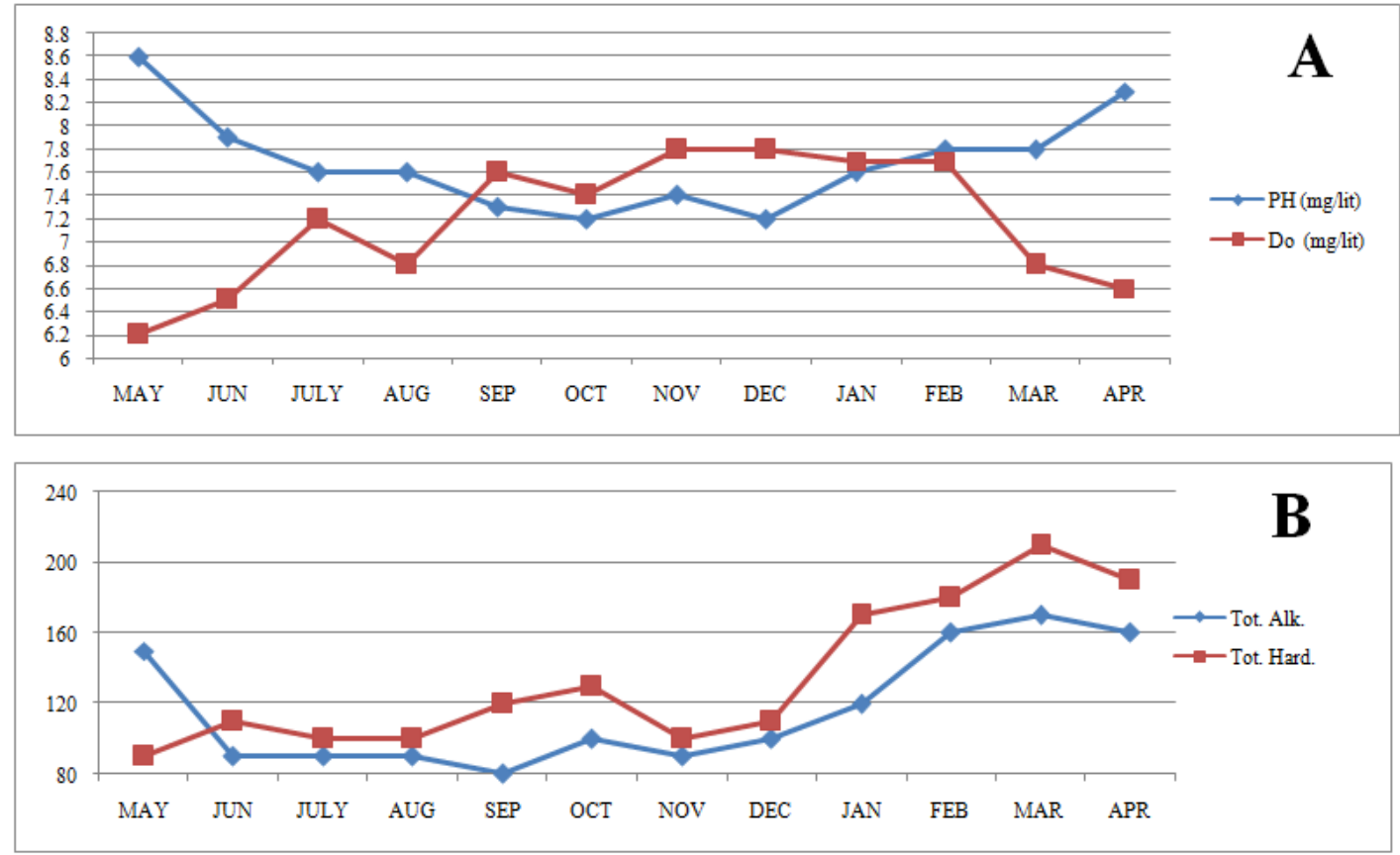

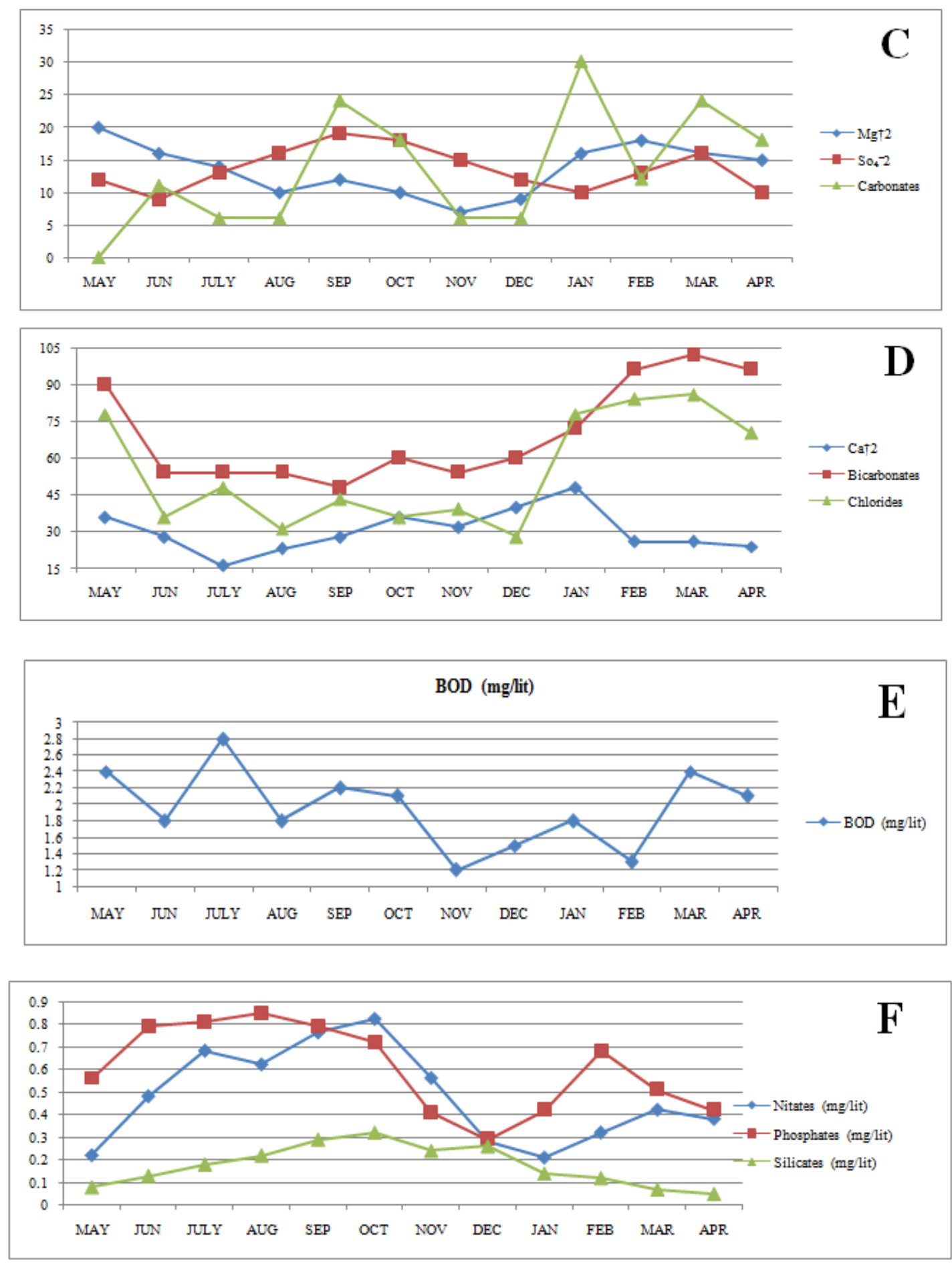

To better understand the trophic structure of an acquatic system, it is important to study the connection between changes in related environmental variables and phytoplankton dynamics (George and Arhonditsis 2004; Ptacnik et al. 2008; Tian et al. 2012b). Diversity of algal components in the aquatic ecosystem serves as a reliable index for biomonitoring of pollution load (Komala et al., 2013). During the study it was observed that the phytoplankton population was comparatively high during winter and early summer and low in rainy. The lower values for the plankton communities during monsoon season may be attributed to high inflow of water from the catchment area changing the hydrology of the system as a result of dilution (LeQuere et al., 2005). Similar results had also been observed by Kumar et al. (2005). The high density of phytoplankton was caused due to increased levels of phosphorus and nitrogen of which the former acts as primary limiting factor. It was because phosphorus is most rapidly and commonly used by vast majority of algae and the algal growth was affected when phosphorus level was below the critical level (Kauppila et al., 2004). Senapati et al., 2001 
observed that $\mathrm{pH}$, dissolved oxygen, bicarbonate, phosphate and transparency enhanced the growth of phytoplankton. Sharma and Singh, 2013, Suresh et al., 2013 studied a close relation between physico-chemical parameters with phytoplankton and observed significant results.

\section{Distribution and Periodicity of Chrlorophyceae}

Fig.3 Shows the abundance and distribution of different class of algae in the study area during May 2014 to April 2015 Among these classes Maximum no of organisms per liter was reported in Chlorophyta class but Euglenophta distributed with less variations in number of organisms per liter during the investigation period

A total of 75 genera belongs to four major groups such as chlorophyceae (32 genera ) Bacillariophyceae (16) Cyanophyceae ( 23 ) and Euglenophyceae (4) were identified. The abundance of phytoplankton 4685000 Organisms/Litre in Venkammacheruvu are Chlorophyta 2388000 Org./Lit./year (50.97\%), Bacillariophyta 888000 Org./Lit./year (18.95\%), Cyanophyta 1129000 Org./Lit./year (24.10\%) and Euglenophyta 280000 Org./Lit./year (5.98\%) were presented in fig.3

Figure 3 : Abundance of different classes in Algae during April 2014 to May 2015 in venkammacheruvu.

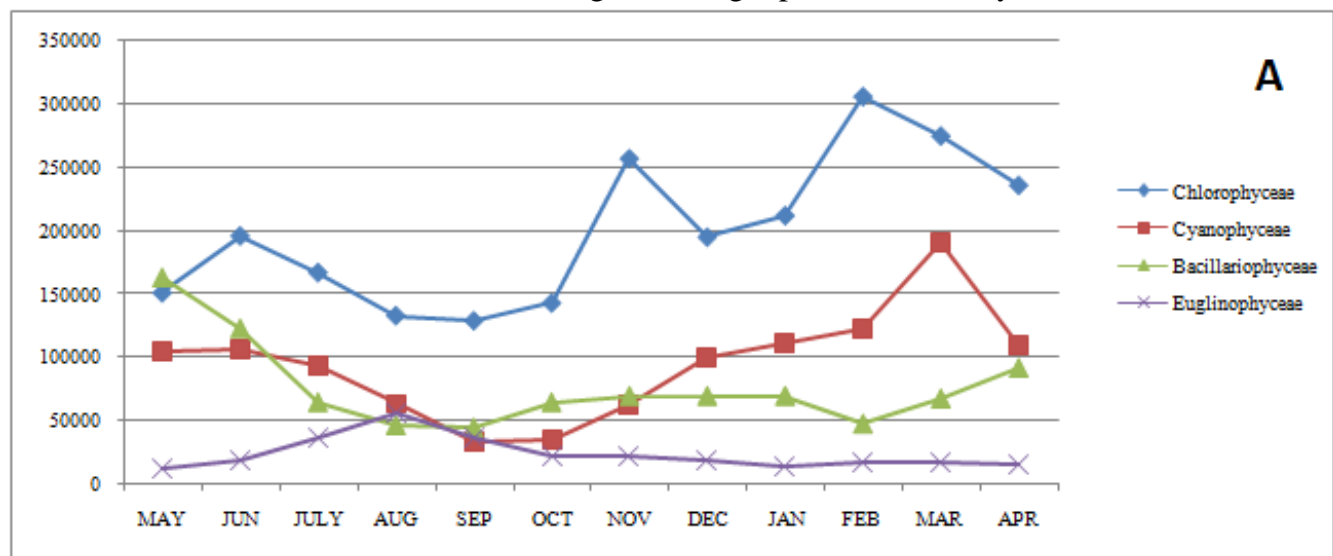

Chlorophyceae group was found dominant during the investigation period of the study area than the other groups with $51.03 \%$ it was observed that chrlorophyceae maximum in February , 305000 org./lit. and minimum September ,128000 org./lit. It was observed that chlorophyceae group flourished during late winter and summer seasons. Sanap et al. (2008), Ravish and Gajendra (2010) found similar results. Maximum density of green algae was recorded in winter when temperature and photoperiod are minimum at venkammacheruvu. The minimum density of chlorophyceae in monsoon may be attributed to the dilution effect due to the rains as well as drifting of algae along with the water. In cold climatic conditions, an increase in organic load commonly leads to a shift in the ecosystem from diatom dominated flora to green and blue green in the form of nutrient input due to human activities in catchment (Patrick, 1970). The different species of Chlorophyceae have differential preference for magnesium and phosphate for their growth and high calcium (48mg/lit)content and low $\mathrm{pH}$ values favour their growth (Munawar, 1974). Total solids and suspended particles prevent growth of Chlorophyceae and its dissolved components have no significant effect indicating that chemical components have less influence on Chlorophyceae (Agale et al., 2013).

The dominant genera are, Asterococcus limneticus, Monoraphidium subclavatum Eudorina elegans, Closterium gracile, Staurastrum gracile,Cosmarium undulatum and Volvax aureus. Of these Closterium, Staurastrum and Cosmerium are considered as desmids which indicate good quality of water and absence of desmids is an indication of heavy pollution of water (Hosmani et al., (2002). Typical species of nutrient rich waters are Oocystis nageli, Ulothrix zoneta, Spirogyra longata, Micractinium pusillum (Sreenivasan et al., 1997) were observed in the pond. According to Standards ISI 10500: 1991- Annexture-I, the species of Coelastrum, Oocystis, Scendesmus, Zygnema, Chlamydomonas, Chlorella vulgaris, and Spirogyra, are found in polluted waters. Of these except Coelastrum and all species were found in the study area in minimum density. The algal community structures thus suggest that the system is still under natural control as is evidenced by the dominance of sensitive species and rare occurrence of tolerant species, this indicate that the water is not much polluted.

Cyanophyceae:The density of cyanophyceae (24.13\%) in Venkammacheruvu was maximum in winter and early summer. Maximum 190000 Org./Lit. in march and minimum in September with 33000 Org./Lit. The dominant genera were Oscillatoria sps., Cylindrospermum sps., Anabaena sps., Merismopedia sps., 
Pharmedium sps., and Aphinotheca sps., present in the pond. Similar result was reported by Patil, 2011.The individual cyanobacterial species have considerable specializations and are intolerant of a high degree of environmental variability (Padisak and Reynolds, 1998). Though the abundance was low in summer in present study maximum 23 species of blue green algae were recorded from study site. Munawar (1974) and Hegde and Sujatha (1997) have reported a direct relationship between nitrates, phosphates, biological oxygen demand and chemical oxygen demand for the abundance of blue-green algae. However, the $\mathrm{pH}$ of Venkammacheruvu was alkaline throughout the study period with maximum in summer and minimum in winter. Harikrishnan et al., (1999) recorded that high $\mathrm{pH}$ values promoted the abundant growth of blue-green algae. The high temperature, stagnation of water, high alkaline condition of water and high concentration of phoshphate and nitrates exhibited the stimulating factor in blue green algae (Pandey et al., 1995). Multiplication of this group coincided with the low contents of phosphates and nitrates (Jyothi and Narasimharao, 2013).

Bacillariophyceae: In Bacillariophyceae was found with 888000 org./lit. during the investigation period 18.98\%. It was observed that maximum in May 162000 org./lit. and minimum 44000 org./lit. in September. In addition the water quality in terms of concentration of organic matter, $\mathrm{DO}, \mathrm{pH}$, and other physical factor play an important role in the distribution of diatoms . Diatoms are reported to absorb phosphates in large quantities than their requirements (Rutner, 1963 and Munawar, 1970). Philipose (1960) has reported direct relation of phosphate with diatoms. In present study, minimum to moderate phosphate were recorded in winter and summer respectively when the diatom populations were moderate to maximum. In additions Nitrates have also been given the prime importance in diatom ecology.(Nandan and Patel, 1986). Some of the pollution tolerant species were also observed in Ankammacheruvu. These are: Navicula cuspidata, N.papula, Gomphonema dichotomous,Nitzschi longisima, Surirella subsalsa, Cymbella gracilis. Similar taxa was also recorded by Nandan and Mahajan, (2007) at Suki Dam, Maharashtra. It is general observation that Cymbella affinis, Fragilaria intermedia , Gomphonema constrictum are commonly found in organically rich waters. And the clean water diatom species are Amphora ovalis, Cymbella delicatula Astronella formosa Navicula cuspidate, Nitzschia clastorium and Pinnularia viridis was also found in Ankammacheruvu.

Euglenophyceae: In the present investigation of Venkammacheruvu the abundance of Euglenophyta showed seasonal variation attributed to temporal variation in physico-chemical parameters. Maximum density of euglenophyta was recorded in the month of August 55000 Org./Lit. and minimum in May 12000 Org./Lit. with $5.86 \%$ of phytoplankton. The similar observations also reported by Hafsa and Gupta (2009). Euglenophyta are found commonly in small water bodies which is rich in organic matter. The presence of Euglena sps and Phacus sps, are a direct indication of beginning of pollution load because both these species in generally, considered to be dominant and tolerant genera of polluted ponds (Alam and Khan, 1996; Palmer, 1980). Kumar et.al (1974) observed the blue green and euglenoid flagellates were mostly associated with organically rich effluents low in DO. Munawar (1972); Hegde and Sujata(1997) were reported that high water temperature, phosphate, nitrate, low dissolved oxygen and carbon dioxide supported the growth of euglenoids. Maximum euglenoids in monsoon can be attributed to influx of rainwater which carries high amount of organic matter from the drainageas observed by Pendase et. al.(2000). Calcium and Magnesium play a great role in stimulating and maintaining euglena blooms (Bhuiyan and Gupta, 2007). Drastic decrease in the population of euglenophyta in winter has been attributed to the use up of essential nutrients during their boom and bust period in monsoon. In conclusion, Venkammacheruvu water supports good diversity and density of phytoplankton with chlorophyceae as most common group while Euglenophyta the least.

\section{References}

[1]. Achary, S., Sahu, M., Mohanty, G., Samatara, A. K., Panigrahy, M. K., Selvanayagam, S. N., Satpathy, K. K., Prasad, M. V. R., and Panigrahy, R. C. Phytoplankton abundance and diversity in the Coastal waters of Kalpakkam, east coast of India in relation to the environmental variables. The Bioscan. 2: 553-568 (2010).

[2]. Anand, N. 1998 Indian Freshwater Microalgae Bishen Singh Mahendra Pal Singh, Dehra Dun. India.1-94

[3]. APHA. 2012. Standard Methods for the Examination of Water and Wastewater. 22nd Ed. American Public Health Association (APHA), American Water Works Association (AWWA) \& Water Environment Federation (WEF), Washington D.C., U.S.A. $1175 \mathrm{pp}$.

[4]. Agale, M. C., Patil J. V ., and Patel, N.G. Study of seasonal variations of Phytoplankton and their correlation with physicochemical parameters of Budaki Medium Irrigation Tank, Shirpur. Dist.Dhule(M.S.) India. European Journal of Zoological Research, 2013, 2 (3):8-16

[5]. Alam, A. and Khan, A. A. 1996. Poll. Res., 15 (3):287- 291

[6]. Bhosale, J. L., Dhumal, S. N. and Sabale, A. B. Phytoplankton diversity of in four lakes of Satara District, Maharashtra state. The Bioscan. 5(3): 449-454 (2010).

[7]. Bhuiyan, J. R. and Gupta, S. 2007. A comparative hydrobiological study of a few ponds of Baral valley .Assam and their role as sustainable water resourses. J. Environ. Biol., 28(4): 799-802.

[8]. Desikachary T.V 1959 Cyanophyta.I.C.A.R.monograph on Algae,NewDelhi,Pp 686

[9]. Chapman, 1962. Tha Algae, MacMillan \& Co Ltd. London.

[10]. Fritsch F.E. 1907. The sub Arial and Freshwater algae flora of the topic Ann. Bot. 21, 235-275 
[11]. George, B. \& Arhonditsis, M. W. 2004. Patterns and mechanisms of phytoplankton variability in Lake Washington (USA). Water Research, 38:4013-4027.

[12]. Edmondson, W.T., (1993): Freshwater Biology $2^{\text {nd }} e d$. ohn wiley and sons, Inc.New York

[13]. Ekhande, A. P. 2010. Hydrobiological studies of Yashwant Lake with special reference to selected biodiversity. Ph. D. Thesis submitted to the Maharaja Sayajirao University of Baroda, Vadodara, India

[14]. Hafsa, S. L. and Gupta, S. 2009. Phytoplankton diversity and dynamics of Chatla floodplain lake . Barak Valley, Assam, North East India - A seasonal study. J. Environ. Biol., 30(6): 1007-1012.

[15]. Harikrishnan K, Sabu T, Sanil G, Paul M, Sathish M, Das MR (1999). A Study on the distribution and ecology of phytoplankton in the Kuttanad wetland ecosystem, Kerala, India. Poll Res 18(3):261-269.

[16]. Hegde G.R. and Sujata T. 1997 distribution of planktonic algae in three fresh water lentic habitat of Dharwad, phykos, 36,49-53.

[17]. Hynes, H.B.N (1971). The Biology of Polluted Water. Univ. Toranto Press, Canada pp. 202.

[18]. ISI, 1991. Indian standard specification for drinking water ISO: 10500, ISI, New Delh.

[19]. Hosmani, S. P., Nagarathna \& J. Mahadev, 2002. Scale forming and corrosive tendencies of water in 20 lakes of Mandy district and its relation to phytoplankton, International Journal of Environmental Protection. 22 (8), pp. 852-857.

[20]. Jyothi Sharma, Alka Parashar, Pratibha Bagre and Imtiyaz Qayoom, Phytoplanktonic Diversity and Its Relation to Physicochemical Parameters of Water at Dogarwada Ghat of River Narmada, Current World Environment, Vol. 10(1), 206-214 (2015)

[21]. Jyothi kaparapu, Mohan Narasimha Rao G. Seasonal distribution of phytoplankton in Riwada Reservoir, VSP, AP, India. Notulae Scientia Biologicae,2013,5(3):1-6.

[22]. Kauppila P., Pakanen H., Raike A., Kiirikki A., Back M. and Kangas S. \& P.,2004.The Baltic waters around Finland; Eutrophication continues despite decreased nutrient loading. In: P. Elorantant(ed.). Inland and Costal waters of Finland. SIL XXIX Congress, Lahti, Finland:8-14.

[23]. Komala H P, Nanjundaswamy L. and Deviprasad A.G. An assessment of plankton diversity and abundance of Arkavathiriver with reference to pollution. Advances in Applied Science Research Vol. 4 pp. 320 - 324. 2013

[24]. Kumar G.P., Bisaria L.M., Bhandari B.G.,Rana and V. Sharma 1974. J. Environ.Hlth 16: 247-25

[25]. Kumar, R., R. D. Singh and K. D. Sharma, 2005. Water resources of India, Current Science. 89 (5).794-811.

[26]. LeQuere C., Harrison S.P., Prentice I.C., Buitenhuis E.T., Aumont O., Bopp L.and Clauster H. ,2005. Ecosystem dynamics based on plankton functional type for Global ocean biogeochemistry models. Global change Biology, : 2016-2040.

[27]. Munawar, M. 1974. Limnological studies on the fresh water ponds of Hyderabad India The biosensor periodicity and species composition of unicellular colonial phytoplankton in polluted environments, hydrobiol., 45(1): 1-32..

[28]. Munawar, M. 1972 Ecological studies of eugleneae in certain polluted and unpolluted environments Hydrobiol., 39(3): 307-320

[29]. Nandan, S. N. and Mahajan, S. R. 2003. Pollution indicating algae of hartala lake of North Maharashtra (India). Trends in Life Sciences (India), 18(1): 49-57

[30]. NandanS.N. and R.J. Patel 1986, Assessment of water quality of vishwamitra river by algal analysis. Indian J. Environ.Hlth.29(2);160-161

[31]. Negi, R. K. And Rajput, A. Diversity of phytoplankton in the freshwater streams of Kumaon Himalaya of Uttarakhand state. The Bioscan. 5(1\&2): 15-19 (2011).

[32]. Palmer, C. M. 1980. Algae and water pollution. Castle House Publication Ltd. New York, pp.4-110.

[33]. Palmer,C.M.1969. Composite rating of algae tolerating organic pollution. British Phycology Bullettin, 5:78-92.

[34]. Pandey, B. N., Mishra, A. K., Das, P. K. L. and Jha, A. K. Studies on hydrological conditions of river Saura in relation to its impact on Biological health. In: Recent Research in aquatic environment. Ed. V.B. AshutoshGoutam and N.K.Aggarwal. Daya Publishing house (1995).

[35]. Patrick, R. 1970. Aquatic communities as indices of pollution: Indicators of Environmental Quality, Plenum Publishing Corporation, New York, pp. 93 - 100

[36]. Philipose, M.T. 1967. Chlorococcales. Monographs on algae. ICAR Publications New Delhi. 1-365.

[37]. Ptacnik, R., Lepisto, L. and Willén, E. (2008). Quantitative responses of lake phytoplankton to eutrophication in Northern Europe. Aquat. Ecol., 42, 227-236

[38]. Pendase D.C., Yogesh shastri and Bharate (2000) Hydrobiological study of percolation tank of village Dasane Ecol Env. cons.6(1) :93-97.

[39]. Philipose, M. T. 1960. , Proc. Sym.Algology, ICAR., 272-291. Philipose, M. T. 1967. Chlorococcales ICAR New Delhi pp 356

[40]. Prescott, G.W., 1984. The Algae: A Review. Koenigstein, Otto Koeltz Science Publishers, 436P.

[41]. Ramchandra, T. V. and Solanki, M. 2007. Ecological Assessement of Lentic Water Bodies of Bangalore. EnvisTechnical Report: 25. Indian Institute of Science, Bangalore.

[42]. Ravish Verma and Gajendra Pal Singh,Seasonal Distribution of Phytoplankton in Laddia Dam in Sikar District of Rajasthan .Research Journal of Agricultural Sciences 2010, 1(4): 366-369 Rutner, F. 1963. Fundamentals of limnology, University of Toronto Press. 295 pp.

[43]. Sanap R R, Pingle S D, Gunale V R and Mohite A K. 2008. Chlorophyceae from Godaveri river at Nashik (M.S.), India. Indian Hydrobiology 11(1): 91-97Senapati, T., Ghosh, S. and Mandal, T. Variation in phytoplankton diversity and its relation with physico chemical parameters of a semi lentic water body of Golapbag, West Bengal, India. International Journal of current research. 3(7) 53-55 (2011).

[44]. Sharma, D. K. and Singh, R. P. Correlation between physico-chemical parameters and phytoplanktons of Tighra reservoir, Gwalior, Madhya Pradesh. International Journal of Security and Networks. 4(1): 90-95 (2013).

[45]. Sreenivasan, A., Pillai, K. V. and Franklin, T. 1997.Limnological study of a Shallow water body (Kolovoi Lake) in Tamilanadu. Indian Hydrobiology, 2(2): 61-69

[46]. Suresh, B., Manjappa, S. and Puttaiah, E. T. Dynamics of phytoplankton succession in Tungabhadra River near Harihar, Karnataka (India). Journal of Microbiology and Antimicrobials. 5(7):65-71 (2013).

[47]. Taweesak Khuantrairong And Siripen Traichaiyaporn. 2008.Diversity and Seasonal Succession of the Phytoplankton Community in Doi Tao Lake, Chiang Mai Province, Northern Thailand, The Natural History Journal of Chulalongkorn University 8(2): 143156 Tian, C., Pei, H., Hu, W. \& Xie, J. 2013. Phytoplankton variation and its relationship with the environmental factors in Nansi Lake, China. Environ Monit Assess. 185(1):295-310. 